\title{
Openness And Inflation: Evidence From The Seven Largest Latin American Economies
}

Rutilio Martinez, University of Northern Colorado, USA Vish Iyer, University of Northern Colorado, USA

\begin{abstract}
The variables of Fisher's Equation of Exchange were estimated as rates of growth for the economies of Argentina, Brazil, Chile, Colombia, Mexico, Peru and Venezuela. These estimations suggest that between 1995 and 2007 for Brazil, and between 1991 and 2007 for the other nations, some inflation failed to materialize. In per-year terms, the missing inflation went from a minimum of 0.9 percentage points in Colombia and Chile, to a maximum of 7.5 percentage points in Venezuela. The missing inflation was attributed to the growing openness of the economies of these nations.
\end{abstract}

Keywords: GDP; real GDP; missing inflation; money supply; openness; tradable goods; velocity of money

\section{INTRODUCTION}

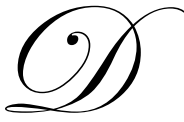

uring the 1980s, the annual average inflation rate in Chile was $20.3 \%$, while it was $23.8 \%$ in Colombia. These rates seem quite high when compared with the $5 \%$ to $12 \%$ average rates of inflation experienced during this decade by most developed nations. Yet, during the 1980s, Colombia and Chile experienced the lowest inflation rates in Latin America (Economic Commission for Latin America and the Caribbean [ECLAC], 2008, Economic Statistics, Table 2.3.1). To bring down their high rates of inflation, the Latin nations started, during the early 1990s, to reduce the rate of growth of their money supply. To reinforce the disinflationary effect of this monetary policy, the majority of Latin nations began implementing, also during the early 1990s, free-market policies. Among these polices was the slow but steady reduction of tariffs and non-tariff barriers. In theory, the increasing openness that results from the tariff and non-tariff reductions helps to restrain inflation because imports of consumer goods increase competition in domestic markets, while imports of capital and intermediary goods increase the efficiency of domestic producers.

This economic proposition is analyzed for the 1995-2007 period for Brazil and for the 1991-2007 period for Argentina, Chile, Colombia, Mexico, Peru and Venezuela. The time period for Brazil is different because this country began its disinflation in 1995, while the other countries began theirs in 1991 or a few years prior. These countries were selected because they are representative of Latin America in terms of GDP and in terms of the attitudes that the Latin governments have exhibited toward free markets. The combined GDP of these seven nations is at least $90 \%$ of Latin America's GDP and the attitudes of the governments of these nations toward free markets have been friendly in the case of Chile, Colombia, Mexico and Peru, while ambivalent in the case of Argentina and Brazil and openly hostile, since 2000, in the case of Venezuela (ECLAC 2008, Economic Statistics, Table 2.1.1.5; and Haber 2009).

As part of the analysis, the correlation coefficient between the rates of inflation and openness was estimated for each country. The rate of inflation was measured as the rate of growth of the national CPI, and the rate of openness was measured by the ratio of imports divided by GDP. The estimated correlation coefficients were quite significant for Chile and Colombia, but had no significance at all for the other nations. The marked difference in the significance of these coefficients was caused mostly by the variability in the rates of inflation. In Chile and 
Colombia, the declining inflation followed a steady and smooth path, but in the other nations, this decline was marked by sharp swings.

Weather inflation declined smoothly, like in Chile and Colombia; or in an erratic manner, like in the other five nations, openness appears to have contributed to this decline. The estimation of this contribution was not done by using an economic model where openness and inflation were directly connected. This estimation was done indirectly through Fisher's Equation of Exchange.

As is well known, the variables of this equation are price level, real income, money, and the velocity of money. These variables were estimated as rates of growth using annual observations of the following data: national CPI, GDP in dollars of 1990, the sum of cash in circulation plus demand deposits (M1), and nominal GDP divided by the sum of cash in circulation plus demand deposits. These average rates of growth were plugged into the proper format of Fisher's Equation of Exchange. When this was done, it was found that the growth of prices had been less than it should have been given the growth of money, real income, and velocity. That is, by estimating the variables of Fisher's Equation of Exchange as percentages or rates of growth, it was found that there was some missing inflation. The missing inflation per year went from $0.9 \%$ in Chile and Colombia to $7.5 \%$ in Venezuela. The missing inflation was attributed to openness because the other possible explanation - money hoarding - was not realistic.

The rest of the paper is organized as follows. Section two discusses the connection that, according to economic theory, exists between inflation and openness. The third section briefly describes the evolution of inflation and openness during the 1995-2007 period for Brazil and during the 1991-2007 period for the other six nations. In the fourth section, the discussion deals with the estimations of the variables that form Fisher's Equation of Exchange and with the interpretation of these estimations. The fifth, and last, section has conclusions.

\section{THE ECONOMIC LINK BETWEEN INFLATION AND OPENNESS}

The first way in which imports put downward pressure on the rate of inflation is by increasing competition in the domestic markets of tradable goods. These are domestically produced goods that compete with imports. Tariffs and non-tariff barriers protect domestic producers of tradable goods by artificially increasing the price of imports, and often, by completely precluding imports from entering domestic markets. Therefore, when tariffs and non-tariff barriers are phased-out, the domestic markets of tradable goods experience an increase in the number of goods that consumers can buy. For domestic producers of tradable goods, such increase constitutes additional competition. Thus, the demands for domestically produced tradable goods that are inferior in price and/or quality to imports will decline or even disappear. Hence, to avoid, or at least to minimize, the loss of market share to imports, domestic producers of tradable goods have to produce better products and/or lower their prices, or at least reduce the rate at which they were planning to increase the prices of their products. These actions restrain the growth of prices of tradable goods and thereby, the growth of the domestic price level. This restraining effect is, however, limited to the share that tradable goods have on the basket of goods that is used to estimate the national price level.

A second way in which a growing openness helps to restrain inflation is by increasing the access of domestic producers to imported capital and intermediary goods. Domestic producers would import this kind of goods if the imported capital and intermediary goods are cheaper and/or of superior quality than the domestically produced capital and intermediary goods. The domestic producers would do this because the better quality of the imported capital and intermediary goods would increase their productivity. In macroeconomic terms, such an increase results in a shift of the aggregate supply curve to the right, which in turn would put a downward pressure in the rate of inflation.

Reallocation of resources is the third way in which imports restrain inflation. Some domestic producers of tradable goods will not survive the removal of the protection offered by tariffs and non-tariff barriers. The labor and capital that the displaced domestic producers stop using may stay unemployed for some time, but in the long run, most of these resources will find employment in activities that do not compete with imports or that produce goods that in terms of price and/or quality, can compete with imports. Either way, the resources that were unemployed as a result of the tariff reduction end up being used more efficiently in other activities, which means that imports generate an increase in domestic output that would not have existed in the absence of the said imports. Thus, the 
import-induced reallocation of resources ends up increasing the supply in some domestic markets, and hence, puts downward pressure on the rate of growth of the price level.

The strength of this pressure will increase as openness increases. However, no matter how open an economy is, in the great majority of countries, domestic goods and services will dominate the domestic aggregate demand and supply, while the prices of domestic goods and services will dominate the domestic price level. Hence, openness cannot set the direction of inflation. This direction is set by the monetary policies of the central bank. If the central bank is pursuing an expansionary monetary policy at the same time that openness is increasing, the inflation rate will not be as high as it would have been without openness, but inflation would still be increasing. That is, openness can contribute to the lowering of inflation, but whether inflation follows an increasing or a decreasing pattern depends on the monetary policy followed by the central bank.

\section{THE EVOLUTION OF OPENNESS AND INFLATION: 1990 TO 2007}

In the literature reviewed, the three most commonly used measures of openness in empirical studies were average tariff, exports plus imports divided by GDP, and imports divided by GDP (Wynne and Kersting, 2007). Of these measures, as explained below, the most appropriate for the analysis done in this paper is the ratio of imports divided by GDP.

Argentina, Brazil, Colombia, Mexico, Peru and Venezuela have cumbersome import regulations and a variety of quotas. These non-tariff barriers obstruct and reduce the imports of these countries. This reduction is, however, excluded from the calculation of the average tariff that these countries report. Such exclusion causes the reported average tariff to overestimate the openness of the economies of these six nations (The Heritage Foundation). Such overestimation ruled out the use of the average tariff as the measure of economic openness.

For the economies of Argentina, Brazil, Colombia, Chile, Peru and Venezuela, the exports plus imports divided by GDP is a volatile indicator of openness. This volatility is caused by the combination of two facts; namely,: the predominance of raw materials and primary goods in the exports of these nations and the well known variability of the prices of these goods in international markets. Thus, for these six nations, the ratio of exports plus imports/GDP indicates changes in the value of their exports rather than changes in the policies that lead to the increase or decrease in the openness of their economies. Hence, for these six nations, this ratio could not be considered as an accurate measure of openness.

The imports of the Latin American countries tend to be dominated by consumer, capital and intermediary goods. Thus, the evolution of the ratio imports/GDP is primarily determined by the evolution of income and barriers to imports. That is, the imports/GDP ratio is primarily determined by domestic economic policies that reveal the relative importance of imports for the domestic economy. For this reason, the imports/GDP ratio was selected as the measure of economic openness.

Table 1 reports, for each country, the rates of inflation and openness in the first and last year of the period of study, the average and standard deviations of the rates of inflation and openness during this period, and the correlation coefficients between these rates. As said in the introduction, the period of study is 1995-2007 for Brazil and 1991-2007 for the other six nations. As was also mentioned in the introduction, the rates of inflation were estimated using the national CPIs, while the rates of openness were estimated by dividing imports by GDPs. The periodicity of the data was annual and the source of the data was the 2008 Statistical Yearbook for Latin America and the Caribbean published by the Economic Commission for Latin America and the Caribbean, the ECLAC.

As can be seen, between 1991 and 2007, there was only one country where openness declined - Venezuela. Despite this decline, the $21.8 \%$ average openness of the Venezuelan economy in this period was higher than the average rate of openness of the economies of Argentina, Brazil and Peru. Argentina, however, exhibited the largest increase in openness - 13.7\% between 1991 and 2007 - while Brazil exhibited the smallest increase - 3.9\% only. Notice, too, that the variability in the rate of openness, as measured by the standard deviation of this rate, was rather small, which suggests that the increase in openness, decrease in the case of Venezuela, followed a very smooth pattern. 
The decline of inflation also followed a smooth pattern in Colombia and Chile. In Mexico and Venezuela, this decline should have also been smooth, but it wasn't. The high variability of inflation in Mexico was caused by sharp devaluation of the peso, Mexico's currency, during 1994 and 1995, while in Venezuela, this high variability is a consequence of populist policies that the government of this nation has been following since 2000. Also experiencing high variability in their declining inflation rates were Argentina, Brazil and Peru. Such variability may have been caused by the high rate of inflation that these nations had in 1991. In the case of Peru, however, the rate of inflation of $-49.1 \%$ experienced in 1991 is misleading. This negative rate came after a 7,840\% inflation rate in 1990 .

Table 1: Openness and Inflation (1991 to 2007)

\begin{tabular}{|c|c|c|c|c|c|c|c|c|c|}
\hline & $\begin{array}{c}\text { Imp/GDP } \\
1991 \\
\%\end{array}$ & $\begin{array}{c}\text { Imp/GDP } \\
\mathbf{2 0 0 7} \\
\%\end{array}$ & $\begin{array}{c}\text { Imp/GD } \\
\text { Average, } \\
\% \\
1991- \\
2007\end{array}$ & $\begin{array}{c}\text { Imp/GDP } \\
\text { Std. Dev, } \\
\% \\
1991- \\
2007\end{array}$ & $\begin{array}{c}\text { Inflation } \\
1991 \\
\%\end{array}$ & $\begin{array}{c}\text { Inflation } \\
2007 \\
\%\end{array}$ & $\begin{array}{c}\text { Inflation } \\
\text { Average, } \\
\% \\
1991- \\
2007\end{array}$ & $\begin{array}{c}\text { Inflation } \\
\text { Std. } \\
\text { Dev, \% } \\
1990- \\
2007\end{array}$ & $\begin{array}{c}\text { Correlation: } \\
\text { Inflation } \\
\text { and } \\
\text { Imp/GDP }\end{array}$ \\
\hline Argentina & 6.6 & 20.3 & 12.8 & 4.2 & 171.5 & 8.8 & 16.8 & 40.7 & $\begin{array}{c}-0.344 \\
(0.177)\end{array}$ \\
\hline $\begin{array}{l}\text { Brazil } \\
\text { (1994- } \\
\text { 2007) } \\
\end{array}$ & 8.2 & 12.1 & 10.7 & 1.7 & 66 & 3.6 & 11.9 & 16.7 & $\begin{array}{l}-0.474 \\
(0.116)\end{array}$ \\
\hline Chile & 24.8 & 33 & 28.6 & 2.8 & 21.9 & 4.4 & 6.8 & 5.6 & $\begin{array}{c}-0.76 \\
(0.0004)\end{array}$ \\
\hline Colombia & 25.11 & 33 & 28.4 & 3.9 & 30.4 & 5.5 & 14.3 & 8.7 & $\begin{array}{c}-0.88 \\
(0.0000)\end{array}$ \\
\hline Mexico & 17.55 & 30 & 25.9 & 4.5 & 22.6 & 3.9 & 12.9 & 10.2 & $\begin{array}{c}-0.15 \\
(0.567)\end{array}$ \\
\hline Peru & 14 & 22.3 & 17.4 & 1.9 & -49.1 & 1.8 & 9.2 & 24.7 & $\begin{array}{c}-0.16 \\
(0.525) \\
\end{array}$ \\
\hline Venezuela & 26.46 & 23.2 & 21.8 & 3.4 & 37 & 19 & 34.6 & 22.7 & $\begin{array}{c}0.997 \\
(0.335)\end{array}$ \\
\hline
\end{tabular}

The estimated correlation coefficient between the rate of inflation and the rate of openness, for each country, is shown in the last column to the right of Table 1. The numbers in parentheses in this column correspond to the $\mathrm{p}$-values of the $\mathrm{t}$ statistics of the estimated correlation coefficients. The correlation coefficients were estimated to determine if there had been any statistical association between the lowering of inflation and the increase in openness in each country. As can be seen, only in Colombia and Chile did this association exist. In the other five nations, as a consequence of the high variability of inflation, there was no statistical association at all between these two variables. This suggests that only in Chile and Colombia was some coordination in the implementation of disinflationary monetary policies and policies to increase the openness of the economy.

\section{MISSING INFLATION}

Independently of their level of significance, the correlation coefficients reported above do not indicate if openness reduced or failed to reduce inflation. Ideally, the effect that openness had on inflation could be estimated by measuring the increase that imports had in the aggregate supply or by measuring the economy-wide intensification in competition and gains in productivity attributable to increases in imports. However, the data needed to make this type of estimation were not found. Thus, to come up with an approximate measure of how much inflation was precluded by the increases in imports, some well established basic macroeconomic theory was used.

This is equation (1) below, which is the well-known Fisher's Equation of Exchange. In this equation, $\mathrm{P}$ is the price level, $\mathrm{Y}$ is real income, $\mathrm{M}$ is money in circulation, and $\mathrm{V}$ is the velocity of money.

$\mathrm{P} \mathrm{Y}=\mathrm{M} \mathrm{V}$ 
In terms of rates of growth, (1) can be written as:

$p+y=m+v$

where $p, y, m$ and $v$ are, respectively, the rates of growth of the price level, real income, money, and the velocity of money. What (2) indicates is that the growth of prices plus the growth of real income are financed by the growth of money plus the growth in the velocity of money. Solving for $p$ from (2) yields:

$p=m-y+v$

This equation describes an equilibrium condition. It implies, for instance, that an increase in the rate of growth of the money supply, an increase in $m$, while $v$ and $y$ are held constant, will result in a simultaneous and proportional increase in $p$ so that equilibrium is restored immediately. In reality, however, a change in $m$ in period $\mathrm{t}$ will result in changes in periods $\mathrm{t}, \mathrm{t}+1, \mathrm{t}+2, \ldots, \mathrm{t}+\mathrm{n}$ in at least one of the other variables until equilibrium is restored. This implies that for a given period of time - for instance a year - (3) will not be observed; i.e., using actual data from a given country to estimate $p_{t}, m_{t}, v_{t}$ and $y_{t}$, will not yield $p_{t}=m_{t}-y_{t}+v_{t}$. However, in economies engaged in a disinflation process, where the economy is moving toward price stability and growth, the following condition should prevail:

$\bar{p} \approx \bar{m}-\bar{y}+\bar{v}$

where $\bar{p}, \bar{m}, \bar{v}$ and $\bar{y}$ are, respectively, the average values of $p, m, y$ and $v$ for a given period of several years. What (4) is indicating is that, on average, the growth of money will be absorbed by the growth in prices, real income, and velocity of money.

Table 2 shows the values of these average rates of growth for the period 1995-2007 for Brazil and for the 1991-2007 period for the other six nations. The data used for the estimation of $\bar{m}$ were the M1 figures reported in the web page of the central bank of each country. These M1 values and the GDPs at market prices were used to estimate the $\bar{v}$ for each nation. The values of the GDPs were found in the Series Históricas de Estadísiticas Económicas 1950-2008 published by the ECLAC. The CPIs used to calculate $\bar{p}$ came, as already mentioned, from the 2008 edition of the Statistical Yearbook for Latin America and the Caribbean also published by the ECLAC. Finally, the GDP of each nation, in dollars of 1990, was used to calculate $\bar{y}$. The data for the estimation of $\bar{y}$ came from the $42^{\text {nd }}, 47^{\text {th }}$ and $52^{\text {nd }}$ issues of the Statistical Yearbook of the United Nations.

Table 2: Average Rates Of Growth Of The Price Level, Money, Velocity, And Real GDP For The 1991-2007 Period

\begin{tabular}{|l|c|c|c|c|c|c|}
\hline & $\begin{array}{c}\overline{\boldsymbol{p}} \\
\mathbf{\%}\end{array}$ & $\begin{array}{c}\overline{\boldsymbol{m}} \\
\mathbf{\%}\end{array}$ & $\begin{array}{c}\overline{\boldsymbol{y}} \\
\mathbf{\%}\end{array}$ & $\begin{array}{c}\overline{\boldsymbol{v}} \\
\mathbf{\%}\end{array}$ & $\begin{array}{c}\overline{\boldsymbol{m}}-\overline{\boldsymbol{y}}+\overline{\boldsymbol{v}} \\
\mathbf{\%}\end{array}$ & $\begin{array}{c}\overline{\boldsymbol{m}}-\overline{\boldsymbol{y}}+\overline{\boldsymbol{v}})-\overline{\boldsymbol{p}} \\
\mathbf{\%}\end{array}$ \\
\hline Argentina & 16.8 & 35.6 & 3.4 & -8.9 & 23.3 & 6.5 \\
\hline $\begin{array}{l}\text { Brazil } \\
\mathbf{1 9 9 5 - 2 0 0 7}\end{array}$ & 11.9 & 21.4 & 1.7 & -0.9 & 18.8 & \\
\hline Chile & 6.8 & 18 & 6.1 & -4.2 & 7.9 & \\
\hline Colombia & 14.3 & 20.2 & 4 & -1 & 15.2 & 0.9 \\
\hline Mexico & 12.9 & 23.3 & 3.4 & -3.6 & 16.3 & 0.9 \\
\hline Peru & 9.2 & 17 & 2.6 & 0.2 & 14.6 & 3.4 \\
\hline Venezuela & 34.6 & 46.1 & 1.9 & -2.1 & 42.1 & 5.4 \\
\hline
\end{tabular}

According to (4), $(\bar{m}-\bar{y}+\bar{v})-\bar{p}$ should be equal to, or approximately equal to, zero. Yet, as can be seen in the last column to the right of Table 2 , for each country, $(\bar{m}-\bar{y}+\bar{v})-\bar{p}$ is equal to a positive number. This number is the average inflation that failed to materialize; i.e., this number is the yearly missing inflation in each country. Money hoarding, it seems reasonable to assume, may have been the cause of the missing inflation. 
Money hoarding is a rational option for consumers facing uncertain economic perspectives and an inflation rate that is very close to zero or negative. Yet, when the economy has been afflicted by inflation rates that are way above zero, consumers are very much aware that the money they hoard will lose value. Hence, since inflation has not been remotely close to zero in any of the seven nations, it is very unlikely that money hoarding occurred in a magnitude that would have precluded increases in the price level.

A more feasible cause of the missing inflation was the growing openness of the economies of these countries. As can be recalled, in the section that discussed the connection between openness and inflation, it was argued that as the economy increased its openness, the imports of consumer, intermediary and capital goods also increased, which in turn increased the aggregate supply, thereby lowering the upward pressure that an expanding aggregate demand put in the domestic price level. That is, as the aggregate supply curve shifts to the right because of the increasing amounts of imports, the price level fails to increase as much as it would have increased in the absence of the growing amounts of imports.

The high rates of growth of real income that Chile, Colombia, Mexico and Argentina experienced lend support to this proposition. These high rates are the values of $\bar{y}$ reported in the third column from the left on Table 2. Such high rates of growth would not have been achieved if the level of imports of intermediary and capital goods would have stayed constant throughout the 1991 to 2007 period.

Also lending some support to the proposition that a growing openness is the cause of the missing inflation is the reduction in the velocity of money. As can be seen, Peru was the only nation for which $\bar{v}$ had a positive, albeit very small, value. For the other six nations, $\bar{v}$ was negative. Given that money hoarding probably did not occur, the reduction in the velocity of money suggests that some domestic currency was used to purchase goods that do not form part of the GDP; that is, to purchase imports.

Finally, notice that the missing inflation was significantly lower in Chile and Colombia than in the other nations. Yet, the correlation between the rates of inflation and openness was significant in Chile and Colombia only; in the other nations this correlation was not significant at all. This should not be considered contradictory since, as can be seen in Table 1, of the seven nations, Chile and Colombia had the lowest variability of inflation, which means that in these two nations, the changes in inflation from year to year were smaller than in the other nations. Thus, in these two countries, the effect that imports could have had in the rate of inflation had to be smaller than in the other countries where inflation experienced sharp yearly swings.

\section{CONCLUSIONS}

Between 1995 and 2007 in Brazil, and between 1991 and 2007 in Argentina, Chile, Colombia, Mexico, Peru and Venezuela, the rates of inflation were consistently below the levels that would have corresponded to the rates of growth of their money supplies. That is, between 1995 and 2007 in the economy of Brazil, and between 1991 and 2007 in the economies of the other six nations, there was some missing inflation.

During these years, according to official data, imports grew in absolute terms as well as a proportion of the GDP of each one of these seven nations. This meant that growing amounts of imported consumer, intermediary and capital goods were entering the domestic economies of these countries. From the perspective of economic theory, the growing amount of imports caused the aggregate supply to increase. This increase absorbed some of the growing supply of money that, in the absence of the growing amount of imports, would have generated higher rates of inflation. That is, basic economic theory suggests that a probable cause of the missing inflation in the seven Latin nations was the growing openness of their economies.

This openness, from Mexico to Argentina, has faced, and will continue to face, stern opposition. The opposition has come, and will continue to come, from both sides of the political spectrum. On the left, political parties with strong connections to organized labor have considered these policies detrimental to the working classes and favorable to institutions like the International Monetary Fund. On the right, organizations of entrepreneurs have campaigned against imports and policies that promote imports because of the extra competition that imports represent. Despite this opposition, the governments of these countries are likely to continue increasing the openness 
of their economies because consumers, regardless of their political convictions, welcome the result of a greater openness - lower inflation and an increased variety of goods in the marketplace.

\section{AUTHOR INFORMATION}

Rutilio Martinez is an associate professor of statistics at the Monfort College of Business of the University of Northern Colorado. He has taught at this school for 17 years. From 2000 to 2005 he was a partner of CG Americas, a Denver firm that promoted businesses between the USA and Mexico. Between 2000 and 2008 he taught a class about Latin American business culture and economics in Furtwangen University in Germany. He has a Ph. D. in economics from Vanderbilt University.

Vish Iyer is a professor of marketing at the Monfort College of Business of the University of Northern Colorado where he has taught for more than 20 years. He has more than 30 publications in peer reviewed journals. He has a $\mathrm{Ph}$. D. in marketing from the University of Texas A\&M. During his career at the Monfort College of Business, he has received several teaching awards

\section{REFERENCES}

1. Banco Central de Chile. Base monetaria y agregados monetarios privados. Promedios/M1. Accessed on June 28, 2010, from: http://si2.bcentral.cl/Basededatoseconomicos

2. Banco Central de la República Argentina. Panorama monetario y financiero. Accessed on August 8,2010, from: http://www.bcra.gov.ar

3. Banco Central de Reserva del Perú. Base Monetaria. Accessed on August 11, 2010, from: http://estadísitcas.bcrp.gob.pe/Monetarias.pdf

4. Banco Central de Venezuela. Circulante, Liquidez Monetaria y Liquidez Ampliada. Retrived on June 30, 2010, from: http://www.bcv.org.ve/C2/indicadores.asp

5. Banco Central do Brasil. Broad Money Supply. Accessed on August 12, 2010, from: http://www.bcb.gov.br

6. Banco de la Republica de Colombia. Agregados Monetarios y Crediticios. Accessed on June 28, 2010, from: http://www.banrep.gov.co/series estadísticas

7. Banco de México. Monetary Aggregates, M1. Accessed on June 28, 2010, from: http://www.banxico.org.mx

8. $\quad$ ECLAC. (2008). Statistical Yearbook for Latin America and the Caribbean. Retrieved on December 14, 2009, from: http://websie.eclac.cl/anuario_estadistico

9. (2009). Series Históricas de Estadísiticas Económicas 1950-2008. División de Estadística y Proyecciones Económicas. Retrieved on August 7, 2010, from: http://www.eclac.cl/deype/cuaderno37

10. Haber, S. (2009, January 31). Latin America's Quiet Revolution. The Wall Street Journal, p W3

11. The Heritage Foundation (2009). The 2009 Index of Economic Freedom. Retrieved on December 19, 2009, from: http://www.heritage.org/index/Ranking.aspx

12. United Nations.Statistical Yearbook. United Nation Publishing Division, New York, NY. $52^{\text {nd }}$ Issue, pp.171-188

13. Statistical Yearbook. United Nation Publishing Division, New York, NY. $47^{\text {th }}$ Issue, pp.135152

14. _L Statistical Yearbook. United Nation Publishing Division, New York, NY. $42^{\text {nd }}$ Issue, pp.159175

15. Wynne, Mark A. and Kersting, Erasmus, K. (2007). Openness and Inflation. Staff Papers. Federal Reserve Bank of Dallas, No.2 pp.4-8 
NOTES 